\title{
POSTIRRADIATION EXAMINATION OF TANTALUM CLADDING \\ FROM PHOTONEUTRON STARTUP SOURCES FOR EBR-II
}

by

R. V. Strain, D. C. Cutforth, and V. G. Eschen

This report was prepared as an account of work
sponsored by the United States Government. Neither
the United States nor the Uinited States Atomic Energy
Commission, nor any of their employees, nor any of
their contractors, subcontractors, or their employees,
makes any warranty, express or imp'lied, or assumes any
legal liability or responsibility for the accuracy, com-
pleteness or usefulness of any information, apparatus,
product or process disclosed, or represents that its use
would not infringe privately owned rights.

EBR-II Project:

Argonne National Laboratory

Argonne, Illinols - Idaho Falls, Idaho

September 1970

Work performed under the auspices of the U. S. Atomic Energy Coumission. 
TABLE OF CONTENTS

Page

ABSTRACT. . . . . . . . . . . . . . . . . . . . 9

I. INTRODUCTION ........................... . . 9

II. POSTIRRADIATION-EXAMINATION PROCEDURES . . . . . . . . . 15

A. Sodium Removal . . . . . . . . . . . . . . . 15

3. Sectioning and Sample Preparation. . . . . . . . . . 15

C. Chemical Analya1s. . . . . . . . . . . . . 17

D. Metallographlc Examination . . . . . . . . . . 18

E. Density Determinations . . . . . . . . . . . . . 18

F. Microhardness Measurements . . . . . . . . . . . 18

G. Diametez Measurements. . . . . . . . . . . . . 19

III. RESULTS AND DISCUSSION . . . . . . . . . . . . . . . . 19

A. Chemical Analyglo. . . . , . . . . . . . . . 19

B. Metallographic Examination . . . . . . . . . . . 19

C. Density Determinations . . . . . . . . . . . . 22

D. Microhardness Messurements . . . . . . . . . . . . 24

E. Dlameter Measuromenta. . . . . . . . . . . . . 25

IV. CONClUSION . . . . . . . . . . . . . . . . . . . . 26

ACKNOWLEDGEMENS. . . . . . . . . . . . . . . . . . . . . 27

REFERENCES. . . . . . . . . . . . . . . . . . . . . . . 28 


\section{LIST OF FIGURES}

No.

Title

Page

1. Tantalum-clad Cylinder and Positioning Fixture. . . . . . . . 10

2. Tantalum-clad Cylinder Inserted in Beryllium Sleeve to Form the Assembled Photoneutron Startup Source . . . . . . . . . . . . 11

3. Relative Axial Fluence Characteristics in Row 8 of the Reactor (Obtained from an Axlal Gamma Scan of an Irradiated Rod from a Depleted-uranium Blanket Subassembly)

4. Relative Positions of the Samples from Source So-1915 Used for Metallography, Chemical Analyses, and Hardness Determinations . . 16

5. Photomicrogrephs of Typlcal Areas of the Tantalum Cladding from Near the Midlength of the Unirradiated Source . . . . . . . . . . 20

6. Fhotomicrographs of Typlcal Areas of the Tantalun Cladding from Near the Midlength of Source So-1915................ 21

7. Density of the Tantalum Cladding and the Percentage of Density Change as Functions of Distance from the Bottom of the Source... . 23 


\section{LIST OF TABLES}

No.

Title

$\underline{\text { Page }}$

I. Operating History of the Sources. . . . . . . . . 13

II. Chemical Analyses of Tantalum Cladding. . . . . . . . . . 19

III. Density of Samples of Tentalum Cladding . . . . . . . . . . 22

IV. Microhardness of Samplee of Tantalum Cladding . . . . . . 25

v. Diameter Measurements of Sources. . . . . . . . . . . 26 
POSTIRRADIATION EXAMINATION OF TANTALUM CLADDING

FROM PHOTONEUTRON STARTUP SOURCES FOR EBR-II

by

R. V. Strain, D. C. Cutforth, and V. G. Eschen

\section{ABSTRACT}

The tantalum cladding from EBR-II antimony-beryllium photoneutron startup sources was examined for evidence of corrosion and changes in physical properties. These sources were exposed to a 4-gpm flow of the EBR-II primary-system sodium during their residence in the resctor. A tantalum-clad source IrradLated to a total peak fluence of about $3.4 \times 10^{22}$ nvt was examined most thoroughly. Optical metallographic examination revealed minor pitting at the outgide surface of the cladding but no evidence of serious corrosion or other microstructural changea. Chemical analysis indicated an increase of $709 \mathrm{ppm}$ oxygen, $98 \mathrm{ppm}$ nitrogen, and 11 ppm hydrogen in the 1rradiated cladding. Chariges in denstty of $2 \%$ (maximum) and changes in mlcrohardness as great as $230 \mathrm{DPH}$ were also observed.

\section{INTRODUCEION}

Flve tantalum-clad, antimony metal cylinders were fabricated for use In an antimony-berylilum photoneutron startup source in the Expeximental Breeder Reactor II (EBR-II). The sources were fabrlcated by welding a lowerend fitting to a tantalum tube, $0.793 \pm 0.001-1 n$. ID, 0.915 $\pm 0.001-1 n$. OD, and 14.75-1n. 1ong. A cylindrical antimony slug, 14-1n. long with a diameter of $0.780 \mathrm{in.}$, was placed in the tube and an upper-end fitting was welded on. The source (the tantalum-clad cylinder) is attached to a positioning flxture as shown In Fig. 1. The cylinder is positioned in a stainless-steelclad beryllium sleeve, as shown in FIg. 2, to complete the source. 


\section{$48 \frac{17}{32}$}
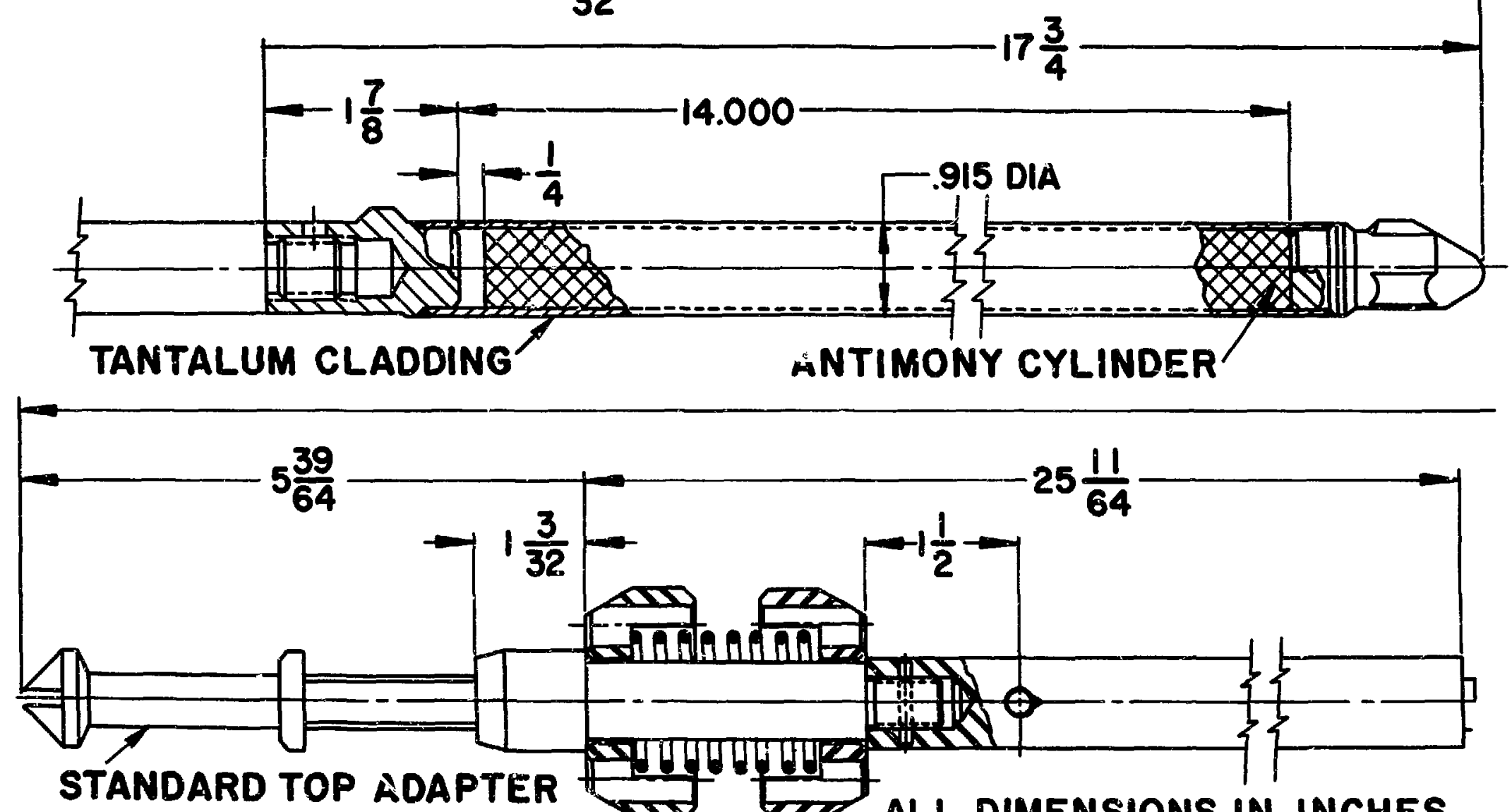

ANTIMONY CYLINDER

STAINLESS-STEEL POSITIONING FIXTURE

Fig. 1. Tantalum-clad Cylinder and Positioning Fixture 


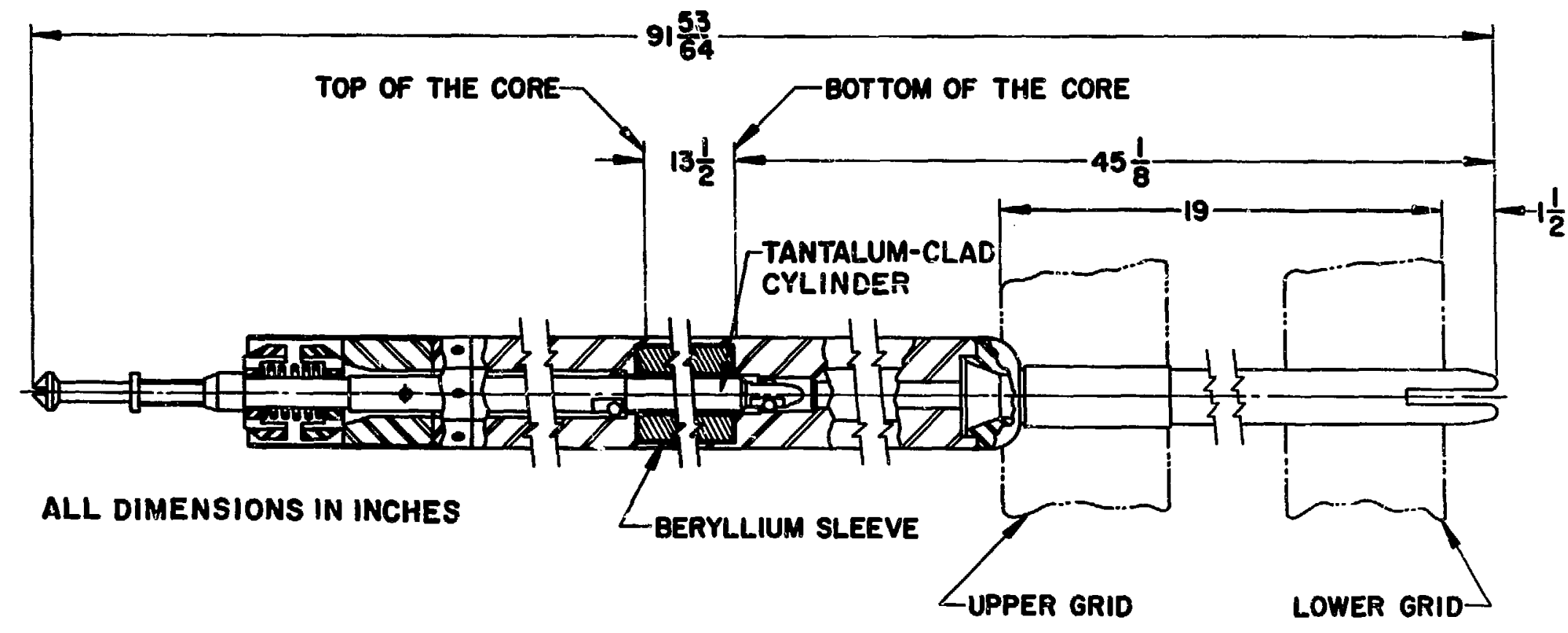

Fig. 2. Tantalum-clad Cylinder Inserted in Beryllium $\mathrm{S}^{2}$ eeve to Form the Assembled Photoneutron Startup Source 
The antimony cylinder was clad to provide mechanical protection for the relatively brittle antimony and to eliminate interaction between the antimony and the primary-system sodium coolant of the EBR-II. Tantalum was used for the cladding rather than the more conventional stainless steel to avold potential pxoblems in compatibility between stafnless steel and antimony. Invegtigations at the Southern Research Institute ${ }^{1}$ and at Battelle Memorial Institute ${ }^{2}$ showed that, of the many materials tested, tantalum had the best corapacibility with molten antimony and that stainless steel was particularly susceptible to attack from molten antimony. In-reactor 1rradiation temperatures above the melting point of antimony were not expected for the source, but tantalum was used instead of stainless steel in the interest of safety.

Four tantalum-clad antimony cylinders (referred to as "sources" hereafter in this report) were installed in the reactor grid during the startup of EBR-II. Three of them, SO-1911, SO-1912, and so-1915, have been removed at Intervals from the reactor to exsmine the tantsium cladding and evaluate its performance in reactor service. These examilations consisted of measurements of diame:er and wall thickness and optical metallographic examinations.

Interest in using tantalum as control material in future LMFBR's resulted in a more comprehensive examination of s0-1915, the source most recently removed from the reactor. Postirradiation examinations of s0-1915 consisted of measurements of diameter and wall thickness; optical metallography; density determinations; and chemfcal analysis for oxygen, nitrogen, and hydrogen. A brief irradiation histocy for each of these sources during their residence in the EBR-II grid is given in Table $I$. The sources were In the blanket region of the reactor, where the neutron flux is not well characterized: consequently, the rotal fluences listed in Table $I$ have an uncertainty of about $\pm 20 \%$. When the antimony cylinder is not being used In the source, it is stored in the reactor core in a hexagonal stainlesssteel cylinder similar in dimensions to the standard subassembly. Figure 2 shows that the midlength of the source was at the axial center line of the core during its residence in the reactor. The change in relative fluence in row 8 of the reactor with distance from the bottoin of the core, as obtained from axial gamma scanning of an Irradiated rod from a depleted-uranium blanket subassemb1y, 13 shown in FIg. 3 . 
TABLE I. Operating History of the Sources

\begin{tabular}{|c|c|c|c|c|c|c|c|}
\hline $\begin{array}{l}\text { Source } \\
\text { Number }\end{array}$ & $\begin{array}{c}\text { Grid } \\
\text { Position }\end{array}$ & $\begin{array}{c}\text { Insertion } \\
\text { Date }^{\mathrm{a}}\end{array}$ & & $\begin{array}{l}\text { Reactor } \\
\text { wer, MWd }\end{array}$ & Flue & $\begin{array}{l}\text { Tota? } \\
\text { nce, } 10^{21}\end{array}$ & \\
\hline so-1911 & $\begin{array}{r}14 \mathrm{BJ} \\
13 \mathrm{~B} 6 \\
14 \mathrm{B5} \\
8 \mathrm{E} 2 \\
13 \mathrm{~B} 6 \\
8 \mathrm{FF} 2 \\
13 \mathrm{~B} 6 \\
7 \mathrm{E5} \\
13 \mathrm{~B} 6 \\
16 \mathrm{Eg} \\
11 \mathrm{E1} \\
13 \mathrm{D} 6 \\
0 \mathrm{ut}\end{array}$ & $\begin{array}{r}5-9-63 \\
9-4-63 \\
9-2-63 \\
9-28-63 \\
10-28-63 \\
10-29-63 \\
11-11-63 \\
11-13-63 \\
12-3-63 \\
6-23-64 \\
6-24-64 \\
6-24-64 \\
3-27-67\end{array}$ & Total & $\frac{1}{12,247}$ & Total & $\left.\right|^{\text {None }}$ & \\
\hline So-1912 & $\begin{array}{r}14 \mathrm{~B} 5 \\
7 \mathrm{E} 3 \\
13 \mathrm{E} 6 \\
7 \mathrm{E} 5 \\
7 \mathrm{E} 6 \\
13 \mathrm{~F} 6 \\
8 \mathrm{A4} \\
\text { Out }\end{array}$ & $\begin{array}{r}9-11-63 \\
9-12-63 \\
10-24-63 \\
11-11-63 \\
12-3-63 \\
6-23-64 \\
3-24-66 \\
4-4-67\end{array}$ & Total & $\begin{array}{c}\frac{\downarrow}{5,570} \\
\frac{6,677}{12,247}\end{array}$ & Total & $\left.\right|_{\substack{0.6 \\
0.0 \\
10.6}} ^{\text {None }}$ & \\
\hline so-1915 & $\begin{array}{l}\text { 7E2 } \\
8 \mathrm{E} 5 \\
8 \mathrm{E} 7 \\
\text { Out }\end{array}$ & $\begin{array}{l}6-23-64 \\
1-9-67 \\
6-27-69 \\
9-5-69\end{array}$ & Total & $\begin{array}{r}9,880 \\
26,274 \\
2,867 \\
39,021\end{array}$ & Total & $\begin{array}{r}9.0 \\
21.0 \\
4.0 \\
34.0\end{array}$ & \\
\hline
\end{tabular}

a. The Insertion date is also the date of removal from the previous position. b. The reactor was operated at zero power until Aug. 1, 1964. 


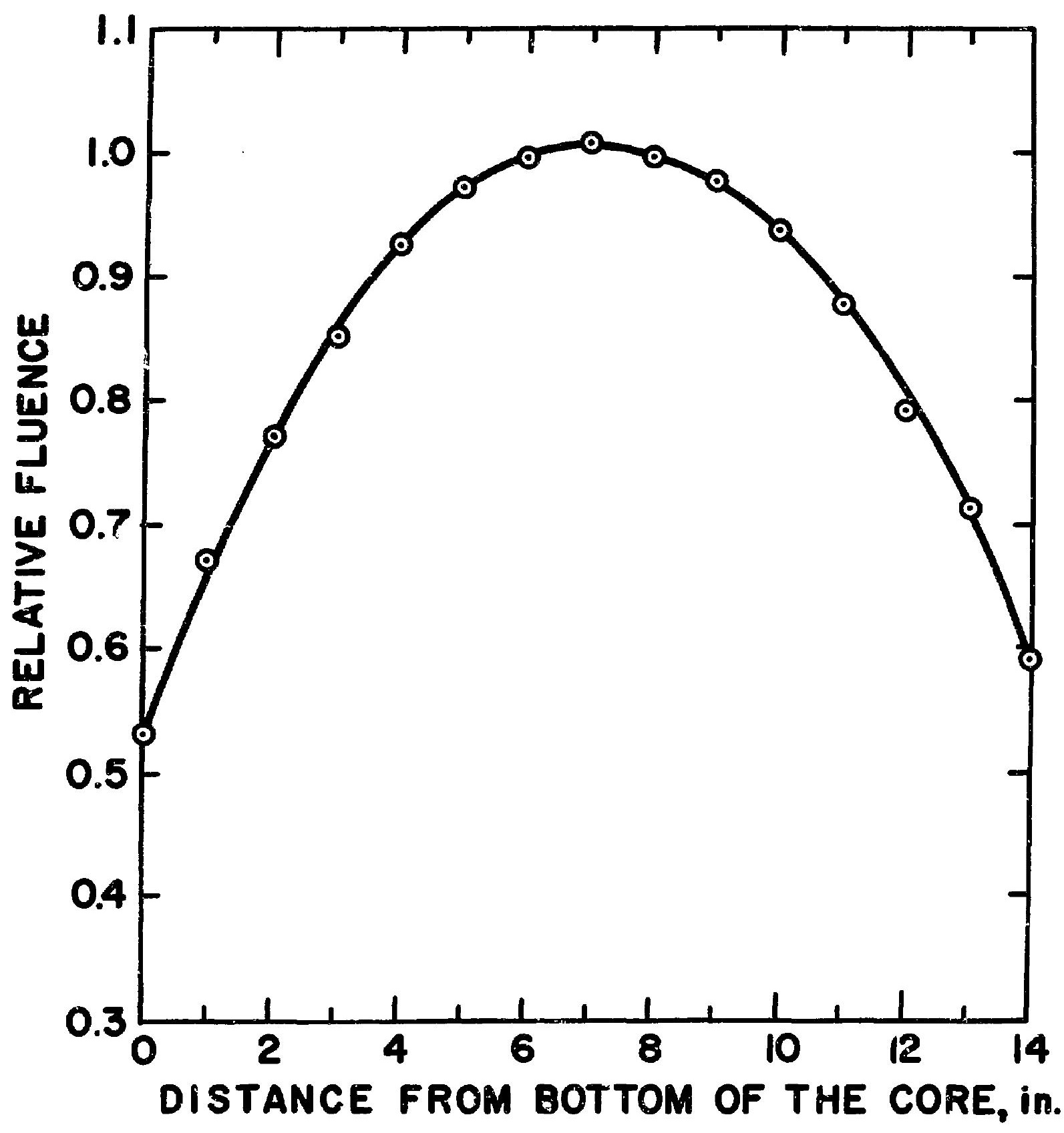

F1g. 3. Relative Axial Fluence Characteristics in Row 8 of the Reactor (Obtained from an Axial Gamma Scan of an Irradiated Rod from a Depleted-uranium Blanket Subassembly) 
The Irradiation temperatures of the sources were assumed to be similar to those of the adjacent subassemblies in the reactor grid because the sodium flow through the source assemblies is only about $4 \mathrm{gpm}$. Calculations indicated that the temperature of subassemblies in row 8 rises linearly from $700^{\circ} \mathrm{F}$ at the bottom of the core to $900^{\circ} \mathrm{F}$ at the top. Gamma heating from the source is not considered to contribute significantly to the temperature of the source assembly. Therefore, the irradiation temperature of source so-1915 is estimated to have varied from $700^{\circ} \mathrm{F}$ at the bottom to $900^{\circ} \mathrm{F}$ at the top.

\section{POSTIRRADIATION-EXAMINATION PROCEDURES}

\section{A. Sodium Removal}

Norma: 1y, irradiated components transferred from the reactor core to the air cell of the FEF are subjected to a sodium-removal operation in which the residual sodium on the surfaccs of the components is oxidized by moist afr or argon and the surfaces are then rinsed clean with water. Because tantalum has poor resistance to corrogion by alkaline solutiona, the sources were subjected only to a purge of dry alr at $10 \mathrm{cfm}$ for $2 \mathrm{hr}$ to prevent contamication of the Interbuilding coffin and to avold corrosion of the cladding itself. This purge was to oxidize the outer surfaces of the residual sodium to reduce the fire hazard during stbsequent handling of the source in the air cell. The source was transferred into the air cell, removed from its stainless steel storage thimble, and transferred into the FEF argon-atmosphere hot cell. The argon-cell atmosphere is maintained at a nominal purity of $40 \mathrm{ppm} 0_{2}, 40$ ppm $\mathrm{H}_{2} \mathrm{O}$, and $7 \% \mathrm{~N}_{2}$. Total exposure time of the source to the air atmosphere, including the oxidation step, was less than $4 \mathrm{hr}$.

\section{B. Sectioning and Sample Preparation}

Source So-1915 was sectioned by using a mechanizal hacksaw in the argon cell. The samples from s0-1911 and so-1912 were sectioned in the air ceil. Three samples about 1/2-in. wide were taken, as shown in Fig. 4. Attumpts to remove the antimony slugs from the tantalum cladding by tapping the sample against a mandrel with the master slave manipulators failed to 


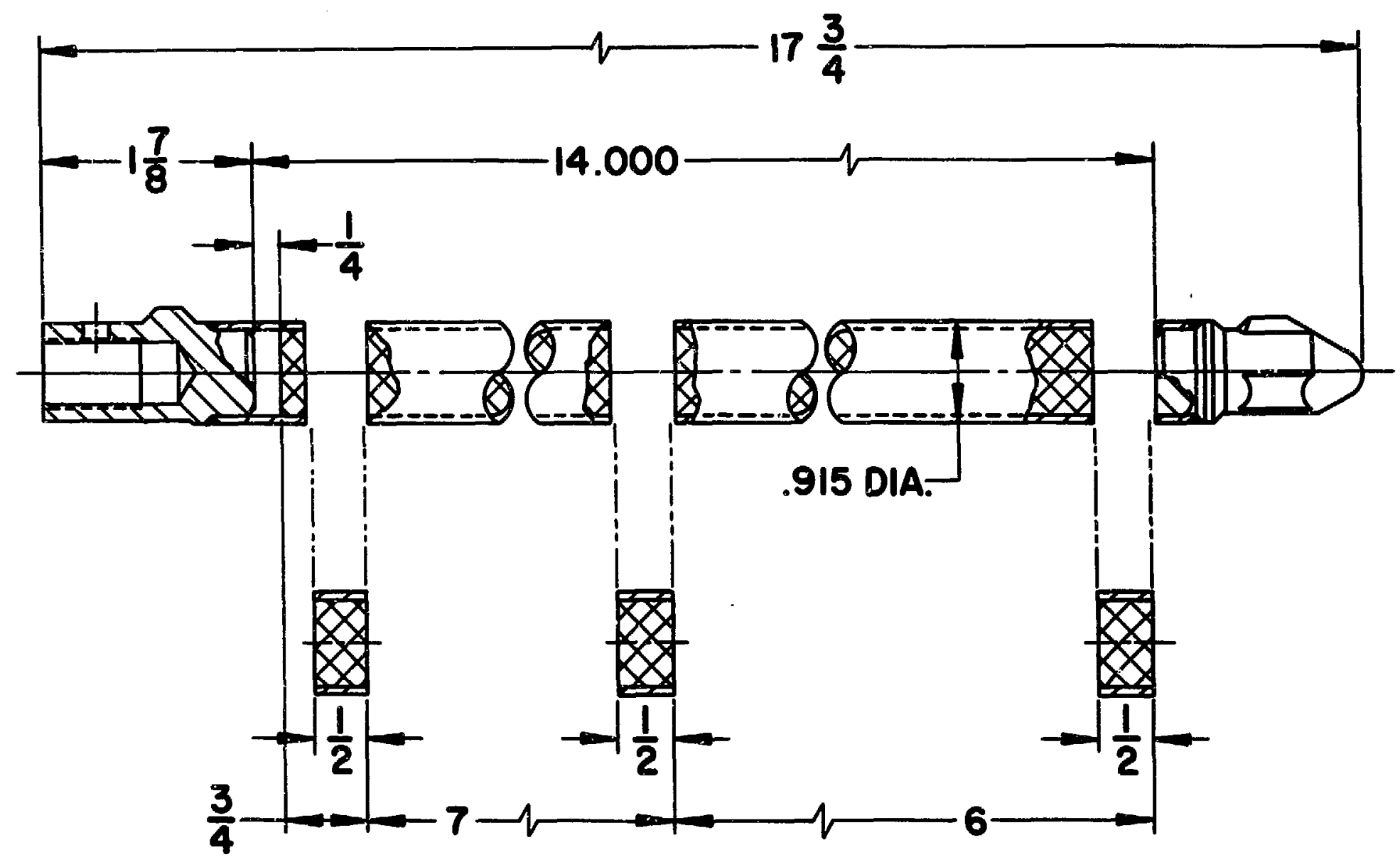

\section{ALL DIMENSIONS IN INCHES}

Fig. 4, Relative Positions of the Samples from Source S0-1915 Used for Metallography, Chemical Analyses, and Hardness Determinations 
dislodge the antimony. The slugs were removed by slitting the tantalum cladding with a cutoff wheel. Because the antimony was not bonded to the tantalum, the slugs were then easily removed from the cladding. The 1/2-in. sections of the sources were transferred to the ANL-Idaho junior cave facility, which contains the analytical-chemistry and metallographicpreparation cells. Small samples of the cladding $(1 / 8 \times 1 / 4 \times 1 / 16 \mathrm{in}$. for metallography and $3 / 8 \times 1 / 4 \times 1 / 16 \mathrm{in}$. for chemlcal analysis) were cut from the samples. The antimony slugs were returned to the FEF for disposal.

The high activity of the samples presented a problem during sectionin and examination in the cave facilities. The sections containing the antimony slugs caused radiation levels of $80 \mathrm{mr} / \mathrm{hr}$ on the operator side of the 2-ft-thick, high-density concrete shielding of the cave hot cells. The metallographic and chemistry samples were cut by using a water-cooled, abrasive cutoff wheel in a closed box within the cell. The oxidation of tantalum produces a light, fluffy oxide powder that is easily transported by air currents. The nine cuts required to obtain the metallographic samples produced enough of this powder to increase the radiation level in the absolute filters of the ventilation system for the metallographicpreparation cell from $100 \mathrm{mr} / \mathrm{hr}$ to $\sim 25 \mathrm{R} / \mathrm{hr}$ at $1-\mathrm{ft}$ distance. The water used during the cutting exhlbited about $100 \mathrm{R} / \mathrm{hr}$ at the same distance. These readings were taken shortly after the source was cut, but about 45 days after the source was removed from the grid. The tantalum sample used for chemical analysis had an activity of $25 \mathrm{R} / \mathrm{hr}$ at I ft 75 days after 1t was removed from the reactor. The metallographic samples produced a field of about $100 \mathrm{mr} / \mathrm{hr}$ through the 6-in.-thick steel shielding of the metallograph1c-examination cell.

Future examinations are expected to be carried out in the Hot Fuels and Examination Facility, where adequate shielding will be available.

\section{Chemical Analysis}

oxygen, nitrogen, and hydrogen were determined by using an inertgas, fusion technique. The samples were melted in a graphite cructble and the geses were picked up in a stream of helium, which was pessed over copper 
oxide. Reaction with the graphite converted the oxygen to carben dioxide and reaction $a_{1}+\mathrm{th}$ the copper oxtde converted the hydrogen to water. The gases were then separated by using cold traps. The water was condensed in an ice bath and the carbon dioxide in a liquid-nitrogen bath, with the nitrogen being collected on molecular sieves at 11quid-nitrogen temperatures.

\section{Meta1lographic Examination}

The metallographic samples were mounted in a cold-seiting epoxy resin (Epon 812) and ground by using 120-, 320-, 400-, and 600-grit silicon carbid paper. The samples were polished with $6-\mu$ diamond paste, then $1-\mu$ and $0.3-\mu$ aluminum oxide on vibratory polishers. The samples were etched with $\mathrm{HNO}_{3}$, $\mathrm{HF}$, and $\mathrm{H}_{2} \mathrm{O}$ in equal proportions. The mlcrostructure of the samples was brought out by altemately polishing and etching them several times.

\section{E. Density Determinations}

The samples were prepared for the density determinations by pickling In nitric acid, and then rinsing, first in deionized water then in alcohol. The densities were determined by the immersion (Archimedes), technique. A constant-temperature bath was used to maintain ti:e carbon tatrachloride immersion medis at a constant temperature of $25.2^{\circ} \mathrm{C}$. The densities of the Irradiated samples and unirradiated control samples were measured with the same apparatus.

\section{F. Microhardness Measurements}

Microhardness was measured with a remotely operated "Tukon" microhardness teister. The accuracy of the unit checked within $1 \%$ of a certified standard having a hardness of 198 (standardized using a 500-g load) at the start and finish of the measurements. 
G. Diameter Measurements

Diameters of sources SO-1911 and S0-1912 were measured with a hand micrometer. The measurements for SO-1915 were made with a dial indicator mounted in a apecial fixture. A machined rod 1 in. In diameter was used as a standard.

\section{RESULTS AND DISCUSSION}

\section{A. Chemical Analysig}

The results of chemical analyses of a sample of the cladding from near the midiength of SO-1915 and a control sample are given In Table II. These results show an apprectable ircrease in the oxygen, nitrogen, and hydrogen content of the cladding. Because of the long time that the sources were in the reactor, these values should be the equilibrium values for these elements in the cladding in contact with the EBR-II primary sodium.

TABLE II. Chemlcal Analyses of Tantalum Cladding (ppm by we1ght)

\begin{tabular}{cccc}
\hline $\begin{array}{c}\text { Source } \\
\text { Number }\end{array}$ & Oxygen & Nitisgen & Hydrogen \\
\hline Unirradiated & 94 & 9 & 2 \\
S0-1915 & 803 & 107 & 13 \\
\hline
\end{tabular}

\section{B. Metallographic Examination}

Photomicrographs of typlcal areas of the microstructure of samples from the unirradiated tantalum and from SO-1915 are shown in Figs. 5 and 6. The optical metallographic examination of samples from the sources revealed some evidence of minor pltting of the outer surface of SO-1915. The pits are assumed to have occurred while the source was in the reactor 


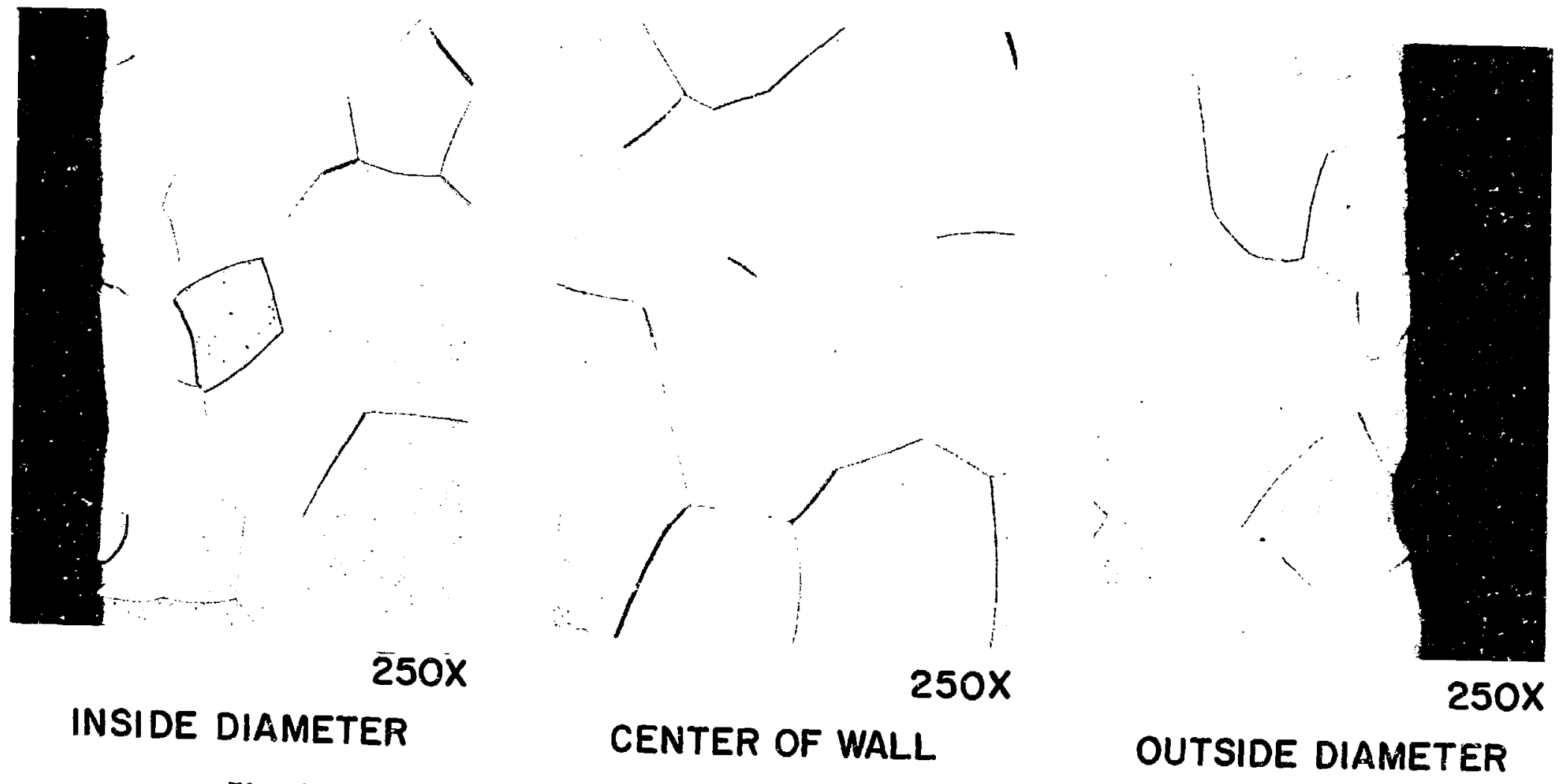

Fig. 5. Photomicrographs of Typical Areas of the Tantalum Sladding from Near the Midlength of the Unirradiated Source 


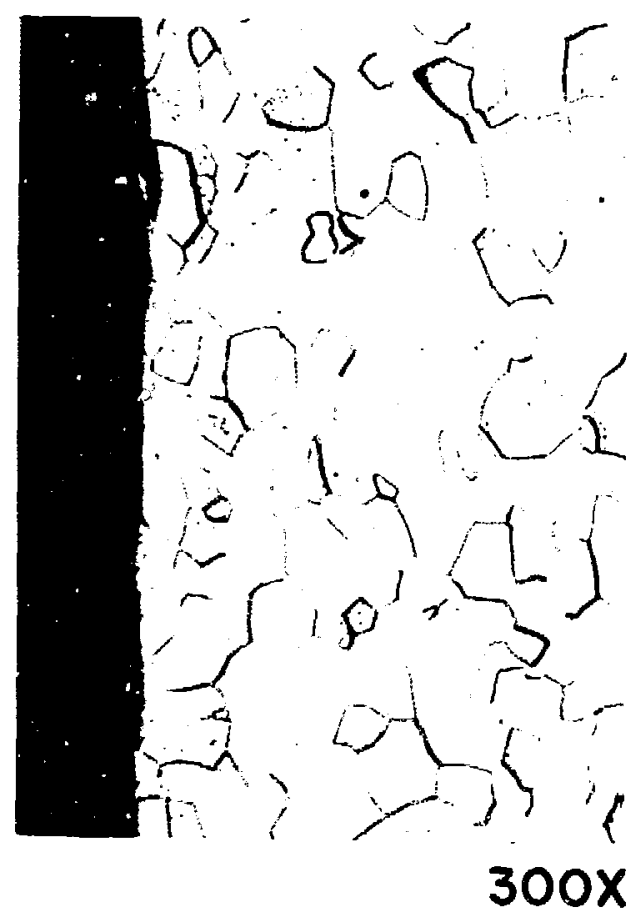

INSIDE DIAMETER

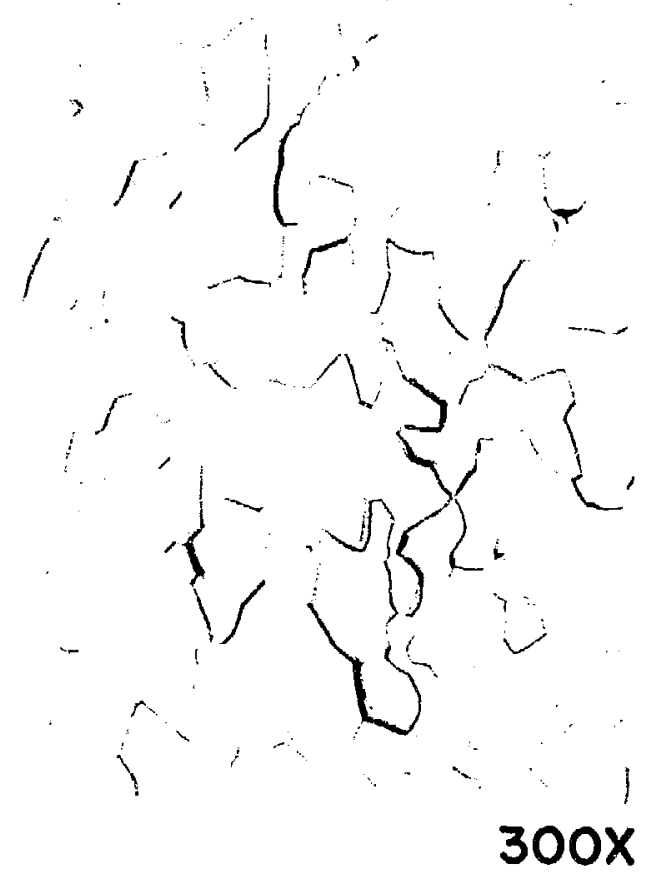

CENTER OF WALL

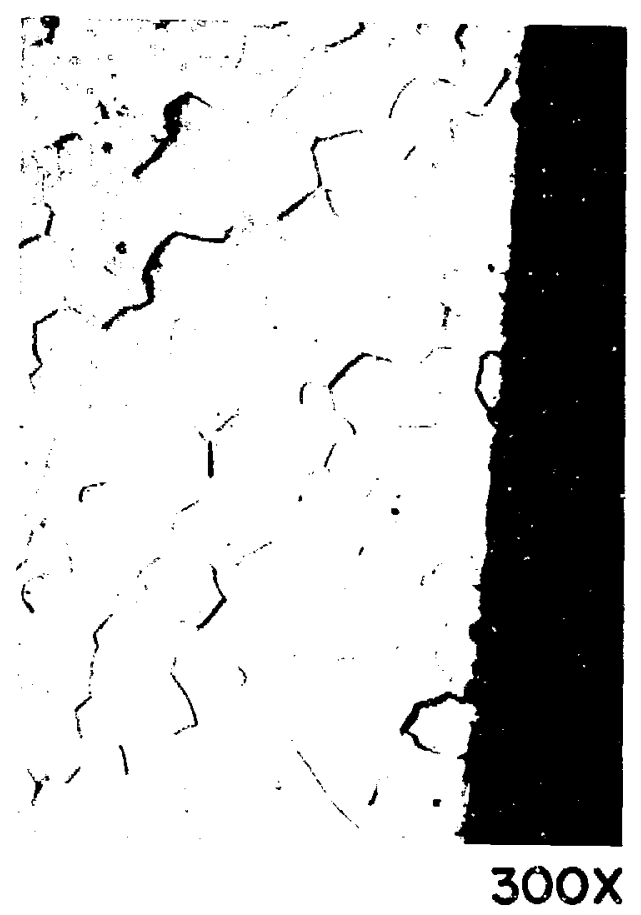

OUTSIDE DIAMETER

Fig. 6. Photomicrographs of Typical Areas of the Tantalum Cladding from Near the Midlength of Source So-1915 
as a result of interaction with the flowing primary-system sodiun. The plttIng might have occurred after the source was removed from the reactor, during atorage, or during sample preparation. However, because the temperature of the source was probably less than $150^{\circ} \mathrm{C}$ during the short atorage perfod, the pitting probably occurred while the source was at higher temperatures in the reactor. No evidence of platelets near the surfaces or at the grain boundaries was observed. Such platelets are characterlstic of oxide, nitride, or hydride precipitates in the microstructure of tantalum. The optical metallography did show that the grain size of the cladding of the Irradiated sources was much smaller than that of the unirradiated source. Because there la no apparent explanation for grain refinement as a result of residence in the reactor, it is speculated that the difference in srain size can be attributed only to fabrisation differences in the originsl material.

c. Dens1ty Determinations

The results of the density determinations are given in Table III.

TABLE III. Density of Samples of Tantalum Cladding

\begin{tabular}{|c|c|c|c|}
\hline \multirow{2}{*}{$\begin{array}{l}\text { Source } \\
\text { Number }\end{array}$} & \multicolumn{3}{|c|}{$\begin{array}{c}\text { Distance from the Bottom of } \\
\text { the Source, In. }\end{array}$} \\
\hline & 13 & 7 & 1 \\
\hline Unirradiated & 16.67 & 16.68 & 16.69 \\
\hline so-1915 & 15.44 & 16.36 & 16.48 \\
\hline
\end{tabular}

The density changes are listed for the various distances from the bottom of the source and are plotted in F1g. 7. Control samples from the unIrradlated source were measured for denstty by using the same apparatus and during the same session as the samples from S0-1915. Although the accuracy of the density apparatus is \pm 0.005 with secondary standards, the accuracy of any density measurement depends on the configuration and size 


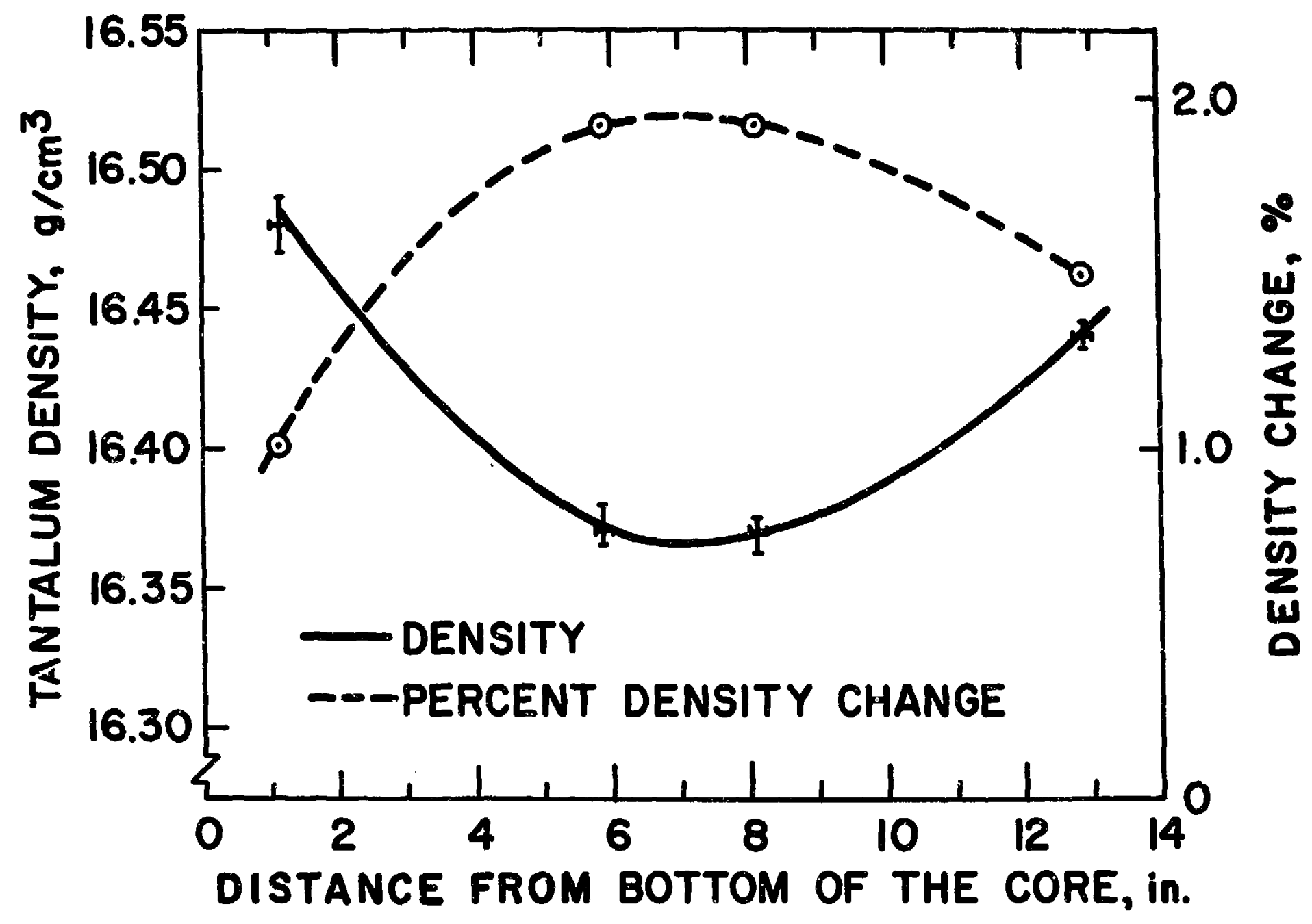

Fig. 7. Density of the Tantalum Cladding and the Percentage of Density Change as Functions of Distance from the Bottom of the Source 
of the sample measured. Another factor affecting the accuracy of these density measurements is the gamma-and beta-decay heating of the sample. No significant decay heating in these samples was noted, because the temperature of the Imersion bath did not increase during long sequences of making measurements on the 1rradiated samples. In addition, determinations were made several times in differeni sequences, with no changes in the results. A rough hand calculation of the beta heating of these samples findicated cuat each sample would produce about $0.02 \mathrm{~W}$ of heat 30 days after the source was removed from the reactor.

The lattice parameter of tantalum is also dependent upon the 1mpurfty content of the metal. Gebhardt ${ }^{3}$ has shown that, in unirradiated tanti um, the lattice parameter shanges from $3.302 \AA$ for high purity tantalum to $3.306 \AA$ for tantalum containing 1 at. \% (0.09 wt \%) oxygen. This change in lattice parameters and increase in oxygen content reduces the theoretical density of the tantalum from 16.689 to 16.536 . If the nitrogen and oxygen content of the 1rradiated tantalum is assumed to change the lattice to the same extent as an equal amount of oxygen would change 1t, the Impurity content of the tantalum would account for a $\Delta V / V$ of $0.92 \%$. The maximum density change observed was $2.04 \%$ near the midlength of the source, whereas a minimum density change of $1.20 \%$ was observed near 1ts bottom. These data indicate that plckup of Impurities from the sodium could contribute significantly to the observed swelling of the tantalum cladding in EBR-II. In contrast, a comparison of the density changes and the shape of the relative axial flux indicates that total swelling is a function of the neutron exposure the cladding received. If a $\Delta V / V$ of $0.92 \%$ is subtracted from the maximum total swelling obtained from these density measurements a maximum swelling of $1.12 \%$ can be attributed, by these density measurements, to the 1rradiationInduced swelling.

\section{Microhardnes 3 Measurements}

The results of microhardness measurements on samples of the unirradiated source, S0-1912, and SO-1915 are given In Table IV. The results listed for the samples from so-1915 are the average values for a microhardness traverse from the outside dlameter to the inslde dianeter of the 
TABLE IV. Microhardness of Samples of Tantalum Cladding (in $\mathrm{kg} / \mathrm{mm}^{2}$ )

\begin{tabular}{cccc}
\hline $\begin{array}{c}\text { Scurce } \\
\text { Number }\end{array}$ & \multicolumn{1}{c}{ Distance from the Bottom } & of the Source, in. \\
\hline Unirradiated & 13 & 7 & 1 \\
S0-1S12 & 98 & 82 & 78 \\
S0-1915 & -- & 277 & -1 \\
\hline
\end{tabular}

tubes in increments of about $0.005 \mathrm{in,}$, starting about 0.002 in. From the outside surfaces. The hardness measurements were very uniform across the wall thickness-within 5\%. These results indicate the absence of large changes in the interstitial content in the material from the inside to the outside of the tubing.

Data on unirradiated tantalum indicate that microhardness is dependent upon itg impurity content. Data by Gebilardt ${ }^{3}$ show that tantalum containing 1 at. \% (0.09 wt \%) oxygen has a microhardness of about 260 $\mathrm{kg} / \mathrm{mm}^{2}$. Seghezzi ${ }^{4}$ has shown that the microhardness of tantalum containing nitrogen varies with the nitrogan content at almost the same rate as the microhardness of tantalum containing oxygen varies with the oxygen content. If the nitrogen and oxygen contents are combined and the combination is assumed to change the microhardness at the same rate as does oxygen, the microhardness of source S0-1915 due to the combined gas content would be about $260 \mathrm{~kg} / \mathrm{mm}^{2}$. The sample from the same location as the sample analyzed for the gas had a microhardness of $302 \mathrm{~kg} / \mathrm{mm}^{2}$. These data indicate that most, if not all, of the changes in microhardness can be attributed to impurities picked up from the EBR-II sodium rather than to irradiation damage.

\section{E. Dlameter Measurements}

The postirradiation measurements of diameters on all three Irradiated sources and the control source are given in Table $V$. None of. the diameters are largex than the maximum specified diameter $(0.916$ in.) 
TABLE V. Dlameter Measurements of Sources

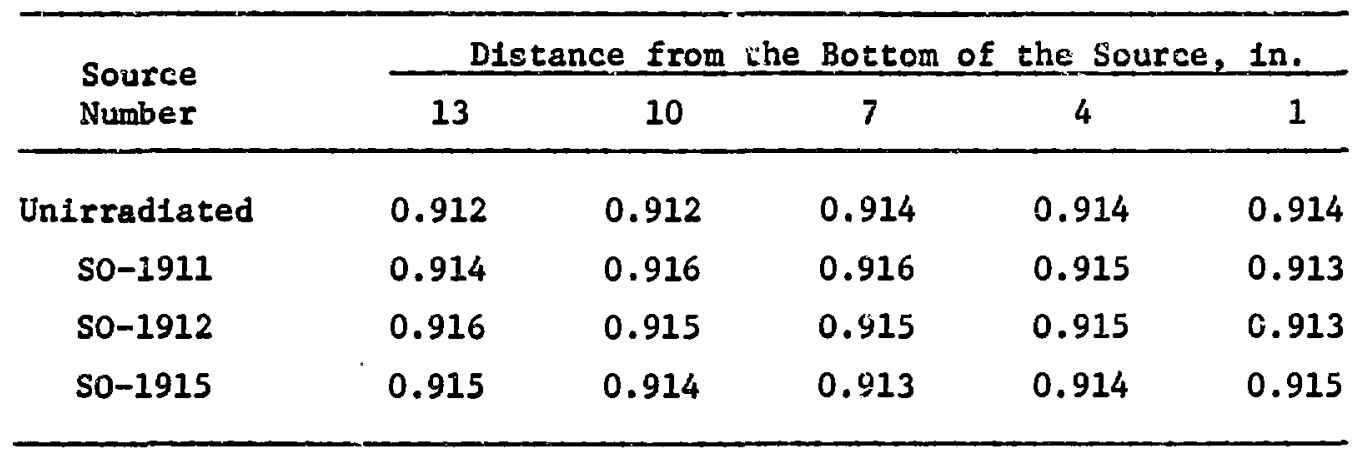

for as-fabricated sources. However, because preirradiation measurements were not made on these sources, whether any diameter change actually oscurred as a result of irradiation is still uncertain.

\section{CONCLUSION}

The tantalum cladding from sources irradiated in EBR-II have shown apprectable changes in microhardness and density, and there is evidence of possible corrosion at the outer surface of the cladding. Unfortunately, the tantalum cladding was not well characterlzed before its use in the reactor; therefore, the conclusions drawn from the results of these examinations are only quelitative. An unirradiated source fabricated at the same time the 1rradiated sources were built was used as a control and examined, but metallographic examinations revealed that it may not be typical of the irradiated sources.

Another factor that complicates correlating the data from the examination of the tantalum cladding is that the sources are not irradiated under conditions typical of the EBR-II environment. The sources spent most their time in the reactor in the phetoneutron-source assembly, in which they were surrounded by a beryllium cylinder. The beryllium acts as a moderator; thus the tantalum is exposed to a neutron spectrum softer than the nominal EBR-II flux spectrum. This factor confuses still further the uncertainty of the fluence values reported for the sources. 
The results of the examination indicate that:

1. The tantalum cladding has not been severely attacked by the EBR-II primary-system sodium, although some pitting was observed.

2. Significant swelling occurred as a result of irradiation of the cladding. The density changes appeared to be a function of the fluence, because the maximum change was observed at the midlength and lesser changes occurred at both the top and bottom end. The amount of awelling (reduction in density) that can be attributed to irradiation damage is unclear because part of the change in density appears to have resulted from chemical changes that occurred while the source was in the reactor.

3. The mechanical properties of the tantalum cladding were altered, as evidenced by the increases in microhardness. The changes appear to have resulted from a combination of Irradiation effects and chemical changes brougl about by the takeup of impurities. Increases in the oxygen and nitrogen content of the tantalum sladding msy have caused much of the observed change in microhardness.

4. Irradiated tantalum can pose significant problems in postirradiation handling because of its high-energy gamma activity. These problems can become vexy significant if small particles are generated during sample preparation.

\section{ACKNOWLEDGEMENTS}

We wish to thank the following ANL people for their assiatance in the examination of the tantalum cladding from the sources:

D. M. Cheney and R. Bastar of the EBR-II Project for the preparation and examination of the metallographic samples;

E. R. Ebersole and $\mathrm{R}$. W. Swanson of the Idaho Division for the density determinations; and

B. D. Hoit and H. T. Goodspeed of the Chemistry Division for the chemical analyses. 


\section{REFERENCES}

1. Private communication (Antimony Corrosion Tests for APDA, Southern Research Institute, Project 734-6, 1957).

2. G. E. Raines, C. V. Weaver and J. II. Stang, Corrosion and Creep Behavior of Tantalum in Flowing Sodium, BMI-1284 (1958).

3. E. Gebhardt, "New Investigations of the Tantalum-0xygen System," 3rd Plangee Seminar, Reutte, Austria, 1958.

4. H. D. Seghezz1, "New Investigations of the Tantalum-Nitrogen System," 3rd Plansee Seminar, Reutte, Austria, 1958. 